\title{
Electron microscopy in Crohn's disease ${ }^{1}$
}

\author{
A. P. R. AlUWIHARE \\ St. Mark's Hospital, London
}

SUMmARY An electron microscopic study of Crohn's disease of the colon is presented. The positive findings that supplement those obtained by light microscopy are: a prominent nucleolus is more common in the lymphocytes of Crohn's disease than in normal lymphocytes or those found in cases of ulcerative colitis; lymphocytes are often observed close to macrophages and epithelioid cells; the epithelioid cells are metabolically active, and have vesicles which contain acid phosphatase but little visible debris; intramural bacteria were identified in six of the 11 specimens of colon with intact epithelia and minimal inflammatory changes.

The possible significance of these findings for the pathogenesis of the disease is discussed.

This ultrastructural study of the colon affected by Crohn's disease was prompted by the paucity of information on this subject, and by the interesting studies of Donnllan (1966) and others in ulcerative colitis and by Chears (1961) and others in Whipple's disease.

All the layers of the colon were examined at the beginning of this study, and subsequently the ultrastructure of other features was studied such as the abundance of lymphocytes and lymphoid aggregates in the lamina propria, the granulomata, and the fissures, which help in the differential diagnosis of Crohn's disease from other non-specific inflammations of the colon (Lennard-Jones and Morson, 1969). Colons from cases of early and established disease were studied and compared with the normal colon and that affected by ulcerative colitis. Preliminary results have been reported elsewhere (Aluwihare, 1969; Aluwihare and Parks, 1970; Aluwihare, 1971a).

\section{Materials and Methods}

Sixteen patients with Crohn's disease were studied, seven of whom had granulomata on light microscopy. There were six control patients with no inflammatory disease and normal aerobic colonic flora and seven with ulcerative colitis. Twelve patients were not on any therapy for Crohn's disease at the time when the specimens were obtained.

${ }^{1}$ Some of this work was presented at the Royal Society of Medicine of London in March 1970, and in collaboration with Mr A. G. Parks of St. Mark's and The London Hospitals at the IVth World Congress of Gastroenterology (Copenhagen) in July 1970.

Received for publication 12 May 1971.
Specimens were taken at operation or sigmoidoscopy and immediately placed in $1 \%$ buffered osmium tetroxide fixative. They were stained in $1 \%$ phospho-Tungstic acid and embedded in Araldite (Causey, 1962). The sections were examined in an AEI EM6 electron microscope.

Consecutive serial sections from the Araldite blocks were studied, one of which would be suitable for light microscopy and the other for electron microscopy, so as to compare the image of a cell stained with toluidine blue for the optical microscope with the fine structure of the same cell. The distribution of acid phosphatase was studied by Gomori's technique (Corrin, Clarke, and Spencer, 1969). Paraffin sections, stained with haematoxylin and eosin or by Gram's method (Davenport, 1960) for light microscopy, were prepared from areas adjacent to those studied by electron microscopy.

\section{Results}

\section{THE EPITHELIUM}

The epithelial cells appear normal even though there may be more oedema than shown in Fig. 1, and there is a heavy infiltrate of inflammatory cells in the lamina propria. Near areas of ulceration the basal parts of the epithelium lose their integrity (Fig. 2). Regenerating epithelial cells have the same appearance as cells in the crypts. Viruses, bacteria, or bacterial residues were not identified in the phagolysosomes ${ }^{1}$ (some of which were cytosegrosomes ${ }^{2}$ ) seen in the epithelial cells themselves.

${ }^{1} \mathrm{~A}$ vacuole containing phagocytosed matter and lysosomal enzymes. 'A membrane bounded body containing cytoplasmic organelles undergoing digestion. 


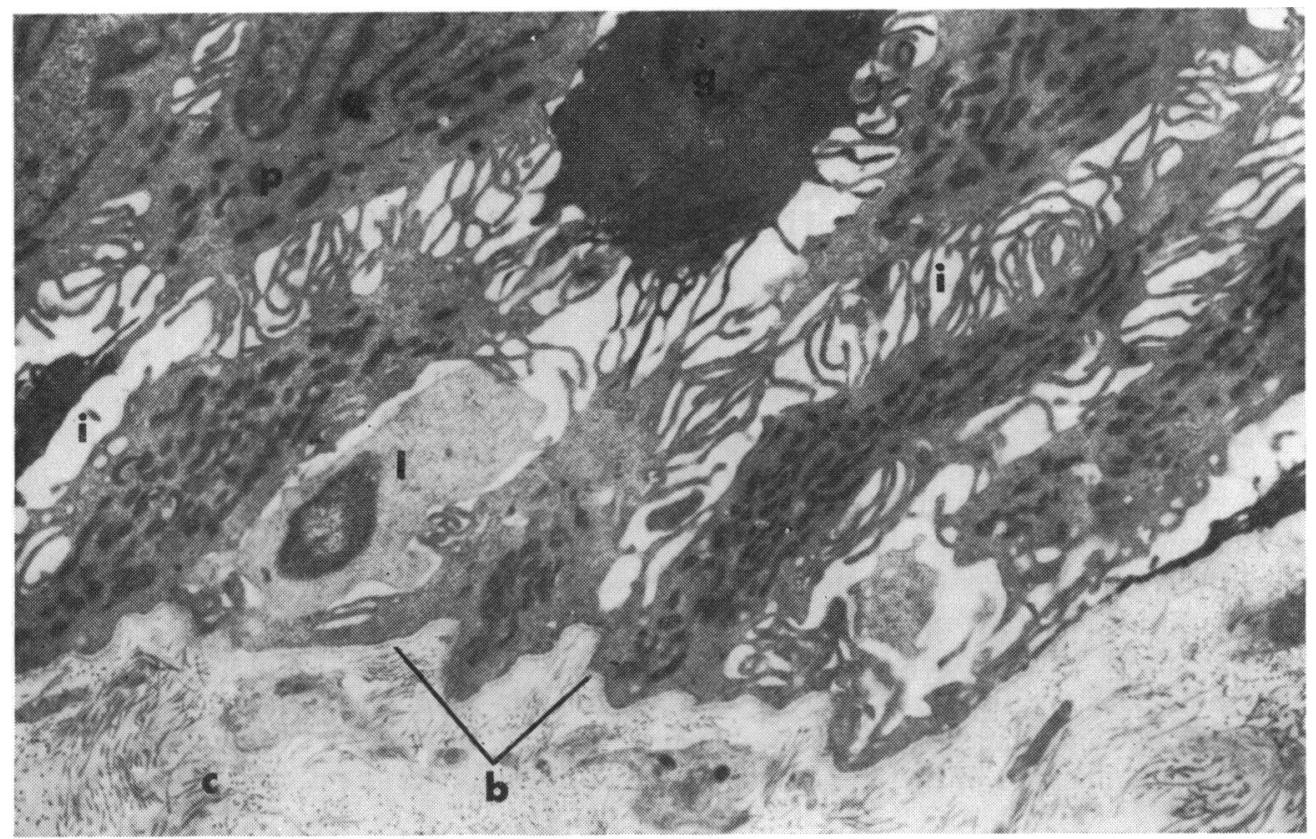

Fig. 1 The basal part of the epithelium in case 5 in Table I over the area in which bacteria were seen. $p=$ principal cell, $g=$ part of goblet cell; $l=$ lymphocyte between epithelial cells; $i=$ intercellular spaces with minimal oedema; $b=$ basement membrane; $c=$ subepithelial collagen in lamina propria. $\times 4,500$

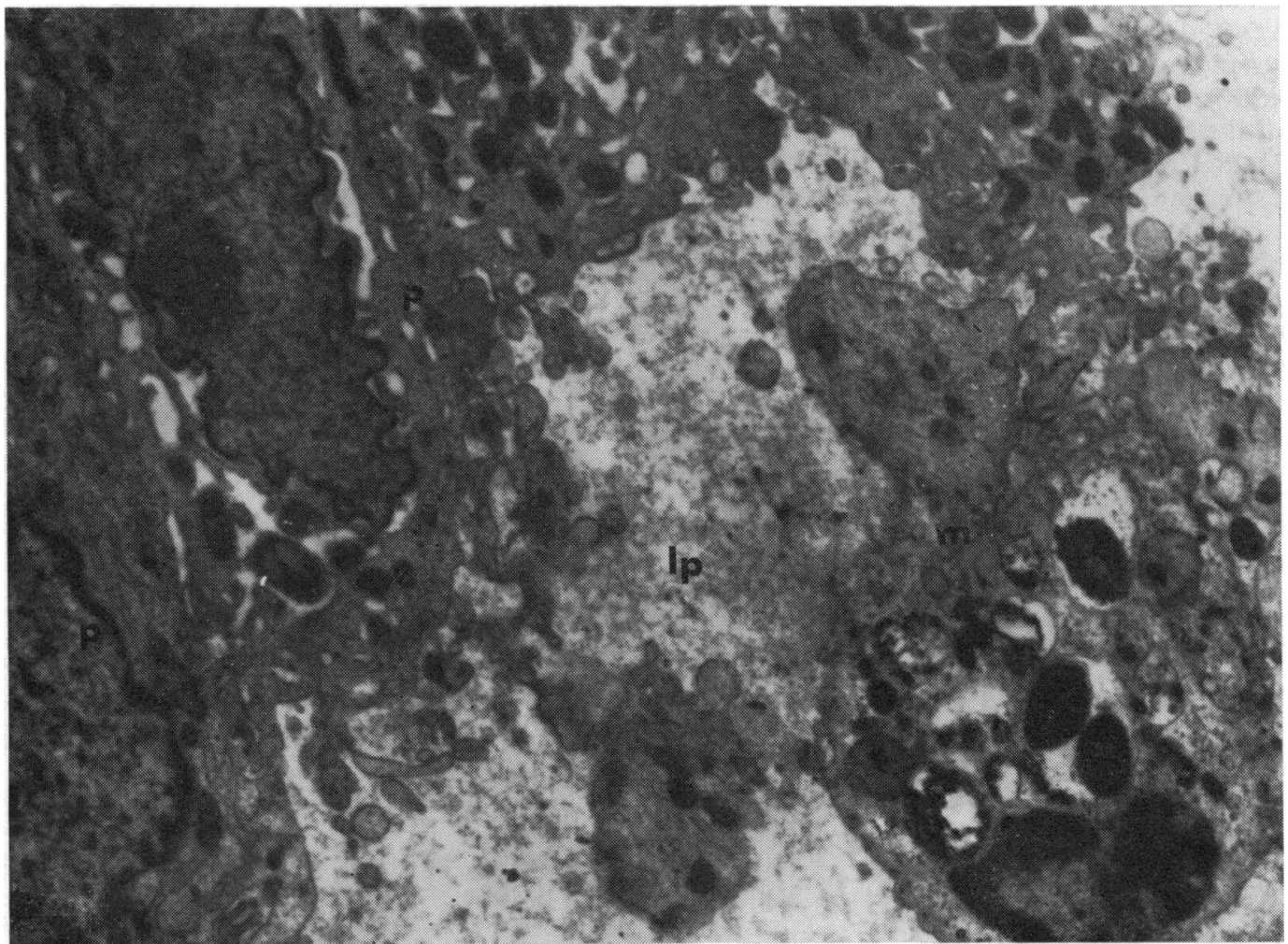

Fig. 2 The basal epithelium near an ulcer. $p=$ principal cells; $m=$ macrophage with debris; $l p=$ lamina propria with no fibrous tissue. $\times 8,000$ 
Fig. 3 Transverse section of an organism (o) in a vacuole (v) in a neutrophil leucocyte. $g=$ granules; $n=$ nuclear masses. $\times 34,000$

Fig. 4 A large macrophage with dense bodies (arrowed), and debris (d) almost surrounding a lymphocyte $(l) . n=$ macrophage nucleus. $\times 3,400$

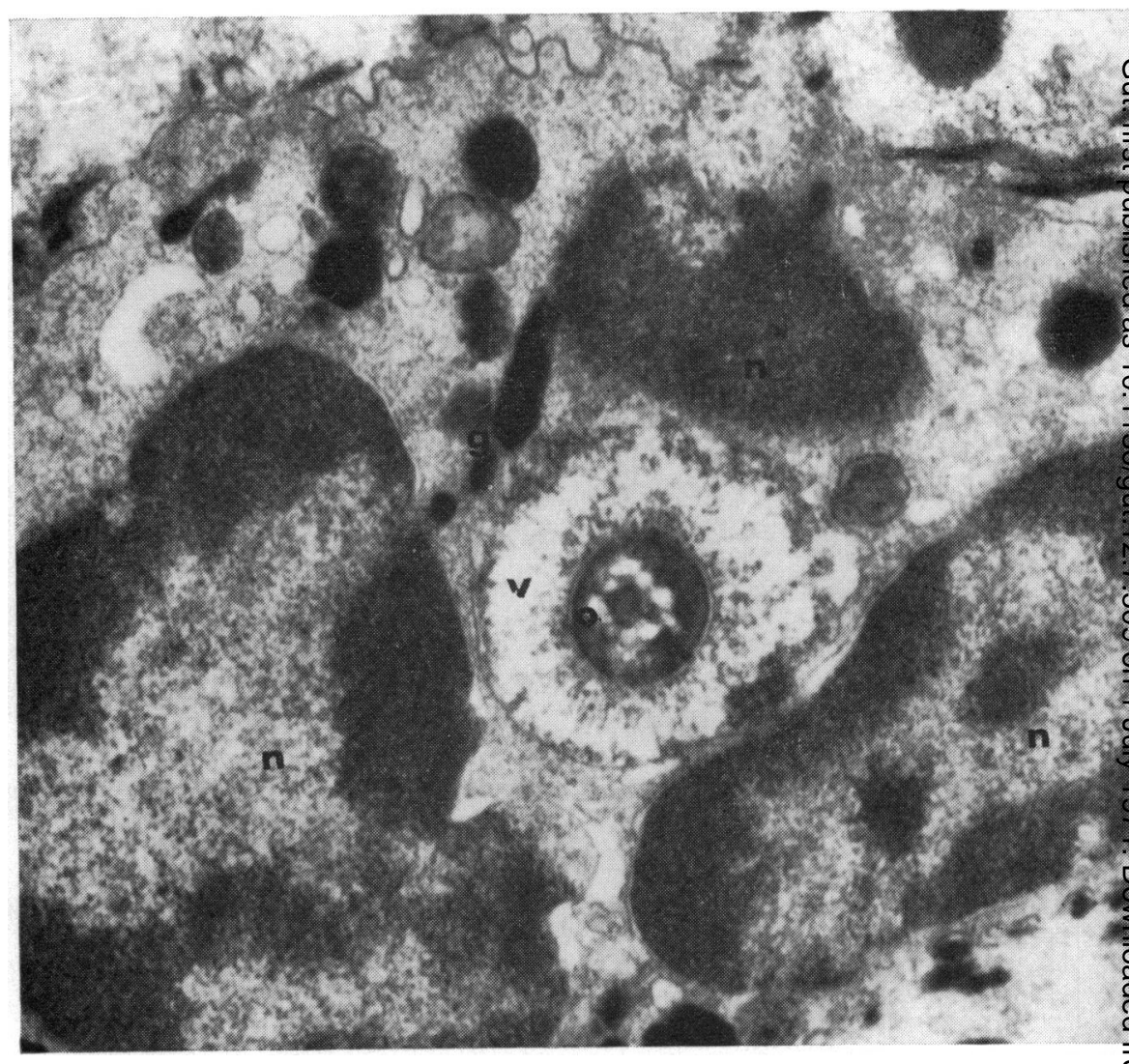

Fig. 3.

FISSURES AND ULCERS

The fissures contain young collagen, red blood cells, inflammatory cells, and bacteria. Bacteria are also seen in shallow ulcers in the epithelium. A transverse section of such an organism in a neutrophil leucocyte is shown in Figure 3.

\section{THE LAMINA PROPRIA}

The subepithelial layer of fibrous tissue may be present (Fig. 1) or absent (Fig. 2) depending on the activity of the local disease, This change appears much later than the increase in the proportions of lymphocytes and plasma cells, and is seen even in the apparently 'normal' lamina propria $1-50 \mathrm{~cm}$ away from the grossly diseased areas. Most of the components of the lamina propria do not differ significantly from those in the normal colon. Such changes as are seen, such as intracellular oedema of the lymphatic endothelial cells, can be seen in ulcerative colitis, though to a lesser extent. Figure 4 shows one of the large macrophages, full of dense bodies and debris, that can be seen in some cases of Crohn's disease, especially those without epithelioid cell granulomata. The macrophage is partly surrounding a lymphocyte. In other cases epithelioid cells are found near lymphocytes (Figs. 6 and 7).

In the submucosa and muscle coats there is

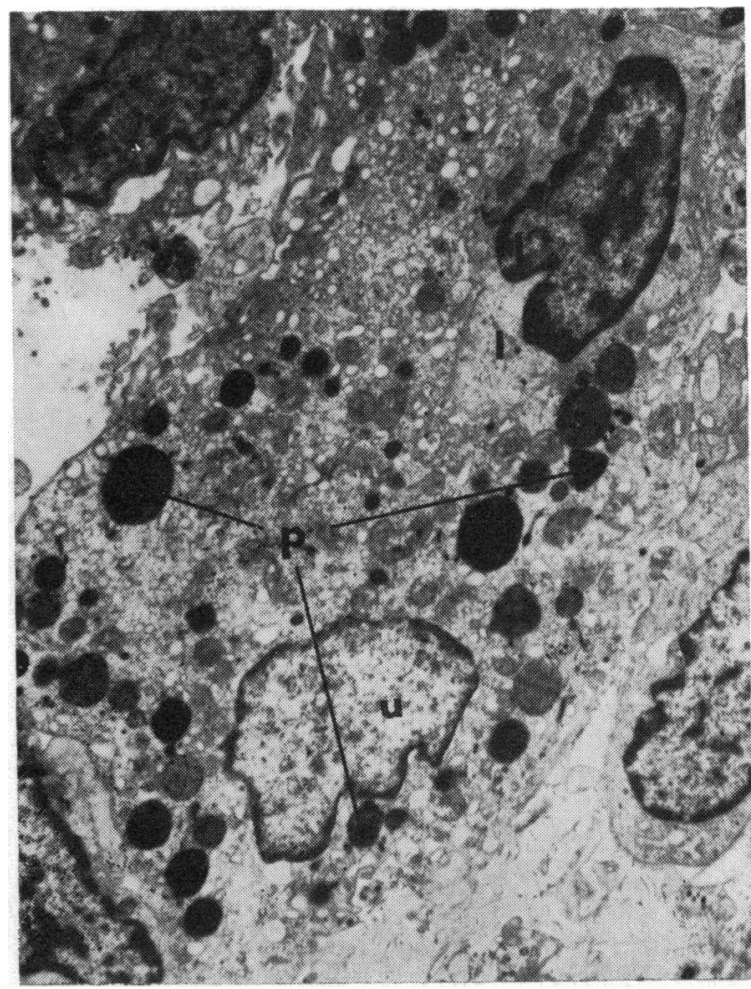

Fig. 4. 


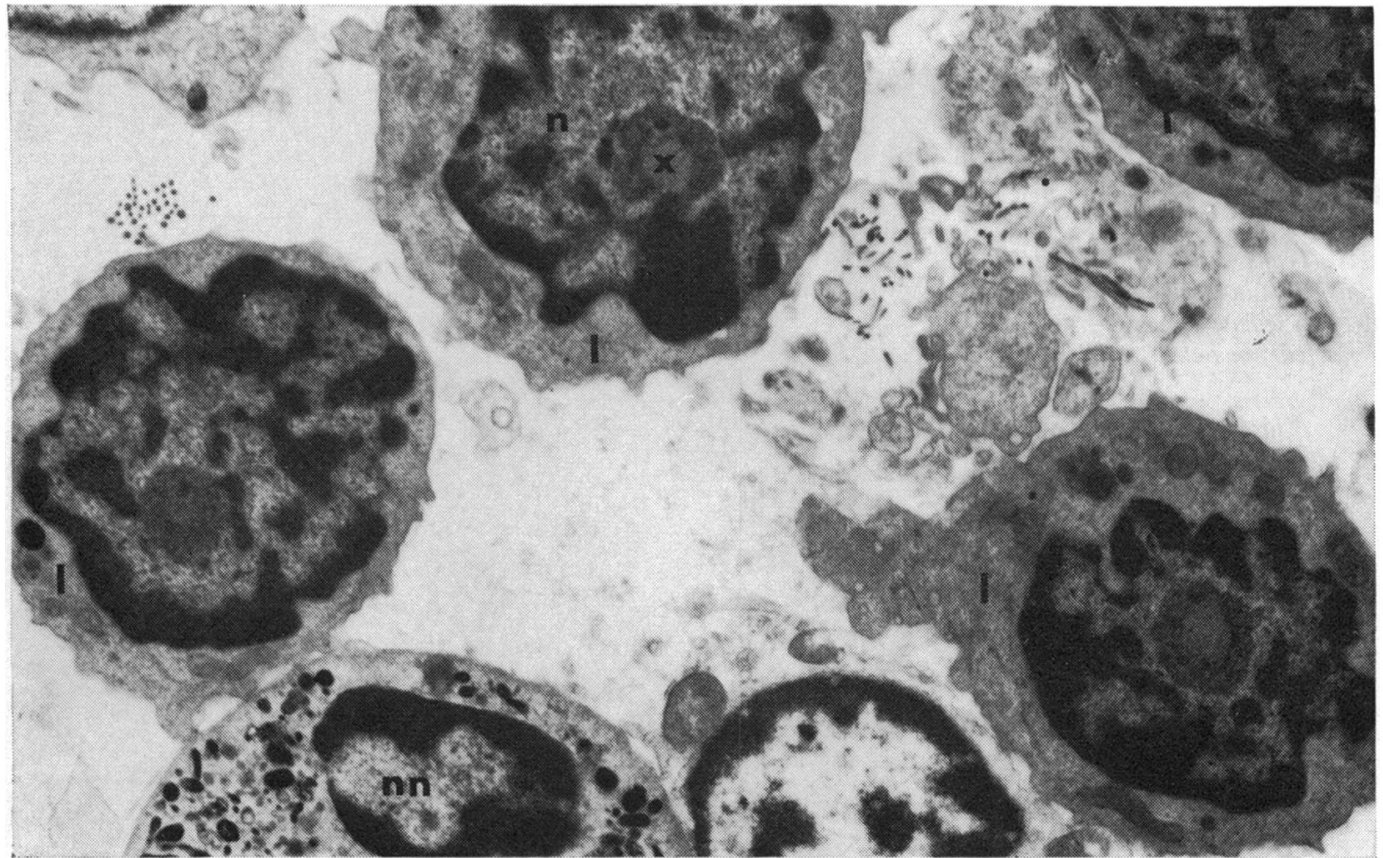

Fig. 5 Lymphocytes $(l)$ in the lamina propria, with prominent nucleoli $(x)$ in their nuclei $(n) . n n=n u c l e u s$ of neutrophil leucocyte. $\times 7,000$

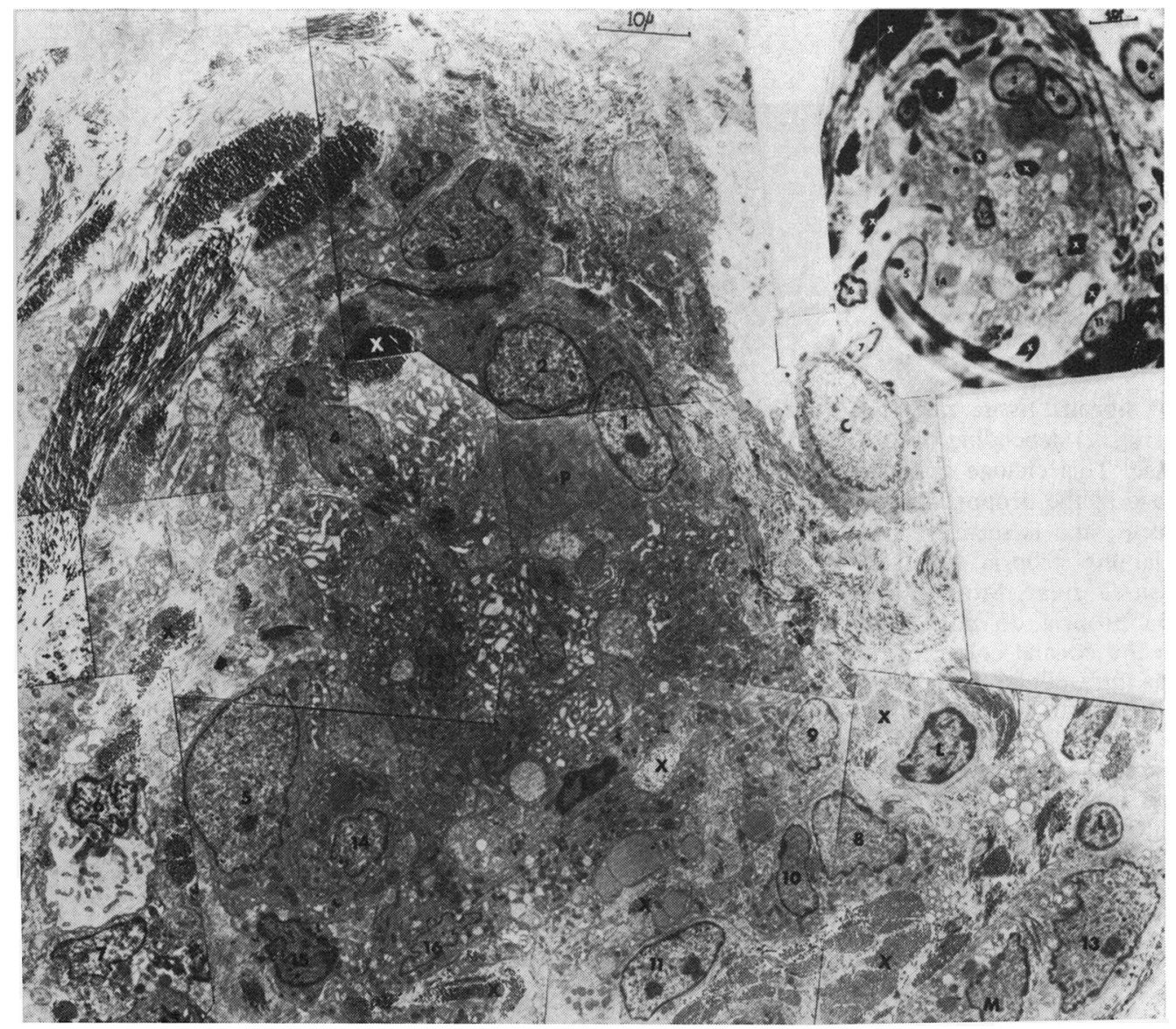

Fig. $6^{1}$ Montage of electron micrographs of a small granuloma in the submucosa. The inset shows the light micrograph of the adjacent serial section. 1-16 epithelioid cells:

$L$ = lymphocytes;

$C=$ endothelial nucleus; $X=$ collagen; $M=$ macrophage; $P=$ plasma cell.

The numbers are in the nuclei of the cells.

'Figure 6 is reproduced by courtesy of the Editor, Proc. Roy. Soc. Med., from Aluwihare, A. P. R. (1971), 64, 162-164.) 


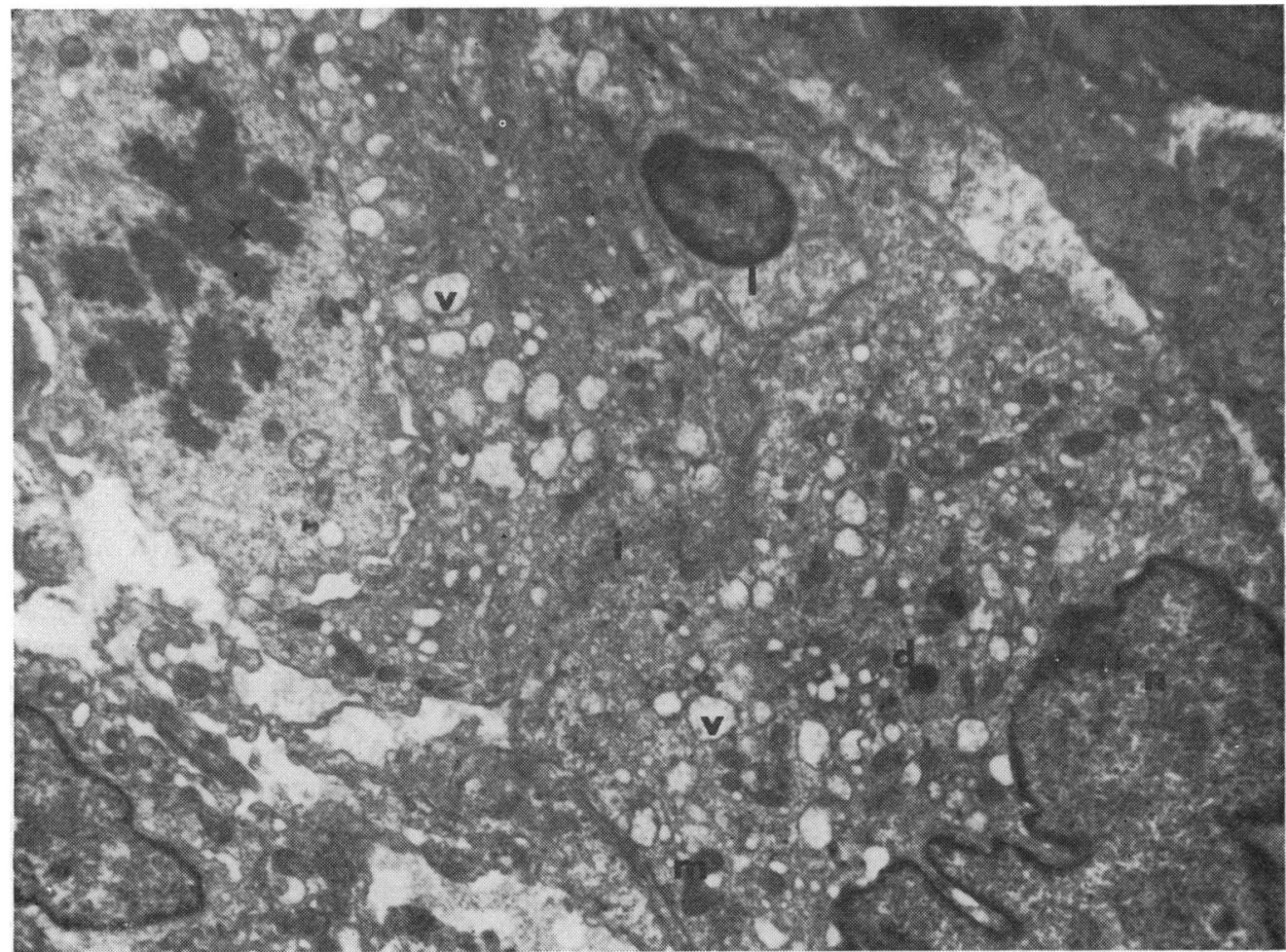

Fig. 7 Three epithelioid cells. $n=$ nucleus; $x=$ mitotic nucleus; $l=$ lymphocyte; $i=$ intercellular margins of epithelioid cells; $d=$ dense body; $v=$ some of the many clear vesicles in the cytoplasm; $m=$ mitochondrion. $\times 3,100$

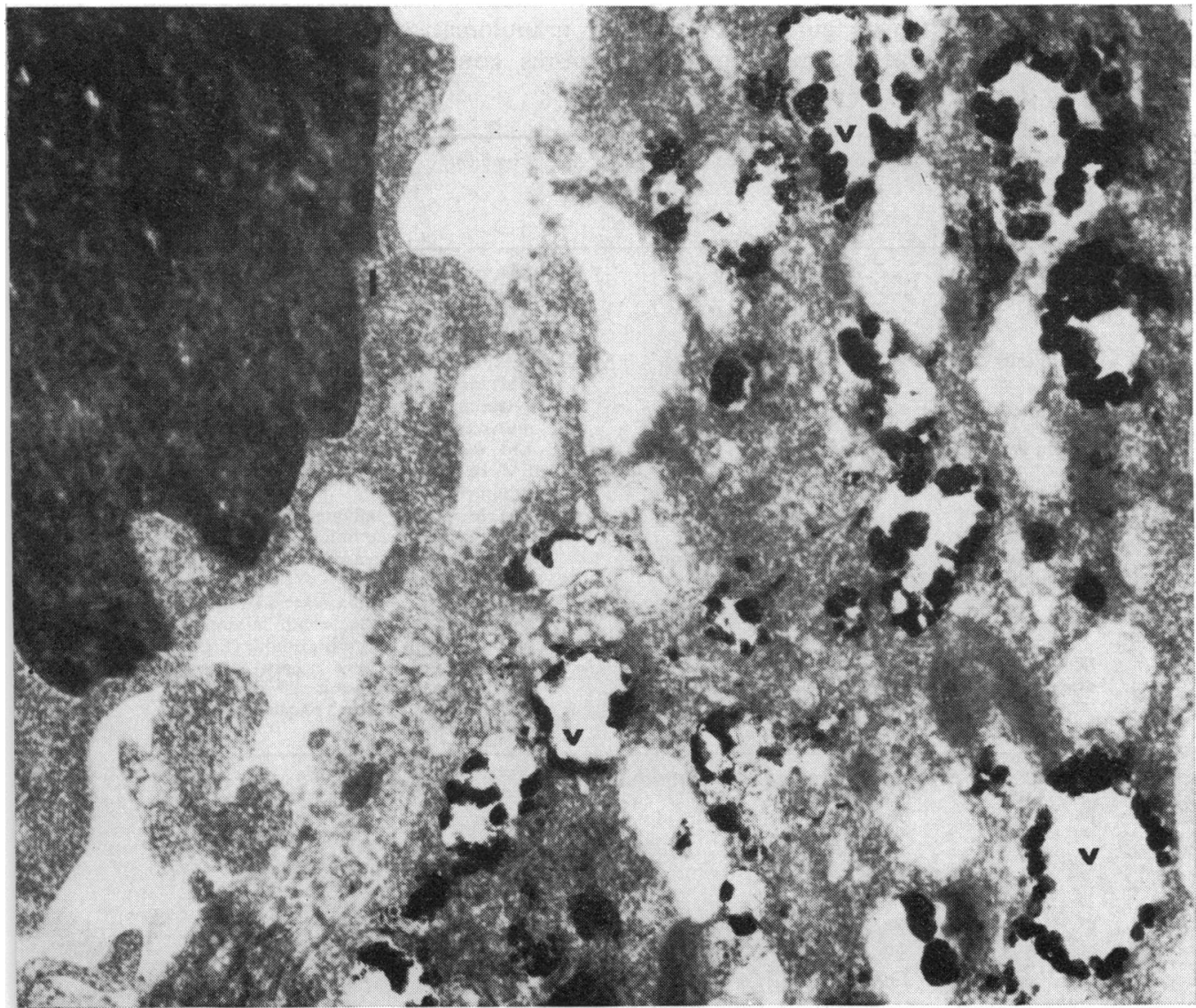

Fig. 8 Part of epithelioid cell and lymphocyte (l). The epithelioid cell has many vesicles (v) with dense black deposits of lead in and around them indicating presence of the enzyme acid phosphatase but no debris. $\times 35,000$ 
increased oedema and intercellular fibrosis with patchy infiltration by inflammatory cells. No specific abnormalities of muscle, nerve, or endoendothelial cells were seen.

\section{THE LYMPHOCYTES}

Fourteen per cent of the lymphocytes in the colon in Crohn's disease show a prominent cartwheellike structure in the nucleus (Fig. 5). This takes on the more usual dense irregular appearance of a nuecleolus in other planes as shown in serial sections. This is seen in only $4 \%$ of the lymphocytes in the normal colon and in ulcerative colitis.

THE GRANULOMATA AND EPITHELIOID CELLS Figure 6 is a montage of electron micrographs of an epithelioid cell granuloma in the submucosa of the colon. The inset shows the light micrograph of the adjacent serial section. The correspondence of structures can be seen. The epithelioid cell nucleus, with dispersed granular chromatin and a prominent nucleolus, has the same appearance in both sections, contrasting with the dense nucleus of the lymphocytes. The cell margins are often very close to each other (see also Fig. 7). The epithelioid cells contain variable amounts of endoplasmic reticulum and ribosomes (for making protein), many mitochondria (for energy production), a Golgi zone (for secretions), vesicles which are not electron dense, and very little debris (phagocytosed matter). Figure 7 shows three cells near each other and a lym- phocyte. One nucleus is in mitosis and the other resembles the nucleus of the macrophage shown in Figure 4. In contrast to the macrophage in Fig. 4 little debris but many clear vesicles are seen in the cells in Fig. 7. Giant cells have the same structural features as epithelioid cells but contain more debris.

The localization of acid phosphatase was studied in the epithelioid cells using the consecutive section technique (as shown in Fig. 6) for determining their identity. The enzyme is found in and around the non-electron-dense vesicles, even though they do not contain any visible debris (Fig. 8).

\section{BACTERIA IN THE LAMINA PROPRIA AND} SUBMU COSA

In 11 cases of Crohn's disease specimens were obtained some distance away from ulcerated or obviously diseased bowel. In six of these, clusters of bacteria were seen in the deeper layers of the colon. The details of the patients in whom definite bacteria were seen are summarized in Table I. In all the cases the epithelium over and around the area in which the organisms were seen was unbroken. Figure 1 shows the epithelium over the area in Fig. 9 which is from case 5 in Table I. In all cases there was an increase in the proportion of inflammatory cells in the lamina propria and some oedema. Light microscopic examination of these areas failed to reveal gross abnormality, although four patients had granulomata in other parts of the bowel. Organisms could not be identified using

\begin{tabular}{|c|c|c|c|c|c|}
\hline $\begin{array}{l}\text { Case } \\
\text { No. }\end{array}$ & $\begin{array}{l}\text { Age } \\
\text { (yr) } \\
\text { Sex }\end{array}$ & $\begin{array}{l}\text { Length } \\
\text { of } \\
\text { History } \\
\text { (mth) }\end{array}$ & $\begin{array}{l}\text { Site of } \\
\text { Gross } \\
\text { Disease }\end{array}$ & $\begin{array}{l}\text { Site of Specimen with } \\
\text { Organisms }\end{array}$ & Comments $^{1}$ \\
\hline 1 & $\begin{array}{l}57 \\
F\end{array}$ & 240 & $\begin{array}{l}\mathbf{R} \text { colon } \\
\text { Sigmoid colon }\end{array}$ & Transverse colon & $\begin{array}{l}\text { LM, oedema and mild inflammation of } \\
\text { colon } \\
\text { EM, submucosal organisms, some } \\
\text { disintegrating (Fig. 10) }\end{array}$ \\
\hline 2 & 51 & 12 & Ileum only & Transverse colon & $\begin{array}{l}\text { LM, normal } \\
\text { EM, increased plasma cells and lympho- } \\
\text { cytes; many cocci straddling muscularis } \\
\text { mucosae (Fig. 11) }\end{array}$ \\
\hline 3 & $\begin{array}{l}28 \\
\mathbf{F}\end{array}$ & 36 & Colon, $\mathbf{R}$ worse than $\mathbf{L}$ & Upper rectum & $\begin{array}{l}\text { LM, oedema only } \\
\text { EM, bacteria in lamina propria and } \\
\text { submucosa }\end{array}$ \\
\hline 4 & $\begin{array}{l}75 \\
F\end{array}$ & 36 & $\begin{array}{l}\text { Anal canal and } \\
\text { lower rectum }\end{array}$ & Upper rectum & $\begin{array}{l}\text { LM, increase of inflammatory cells } \\
\text { EM, bacteria deep in lamina propria }\end{array}$ \\
\hline 5 & $\begin{array}{l}28 \\
\text { F }\end{array}$ & 96 & $\begin{array}{l}\text { Ileum and } \\
\mathbf{R} \text { colon }\end{array}$ & Distal transverse colon & $\begin{array}{l}\text { LM, possible increase in inflammatory } \\
\text { cells } \\
\text { EM, minimal oedema; excess lymphocytes } \\
\text { and plasma cells. Bacteria in lamina } \\
\text { propria, extra- and intracellular (Fig. 9) }\end{array}$ \\
\hline 6 & $\begin{array}{l}19 \\
\mathbf{F}\end{array}$ & 21 & $\begin{array}{l}\text { Ileum, caecum, } \\
\text { descending colon }\end{array}$ & Upper rectum & $\begin{array}{l}\text { LM, mucosal oedema; otherwise normal } \\
\text { EM, increase in plasma cells and } \\
\text { lymphocytes; oedema; bacilli in lamina } \\
\text { propria and submucosa }\end{array}$ \\
\hline
\end{tabular}

Table I Patients in whom bacteria were found in the colon with minimal histological changes

${ }^{1} \mathrm{LM}=$ light microscopy

$\mathrm{EM}=$ electron microscopy 


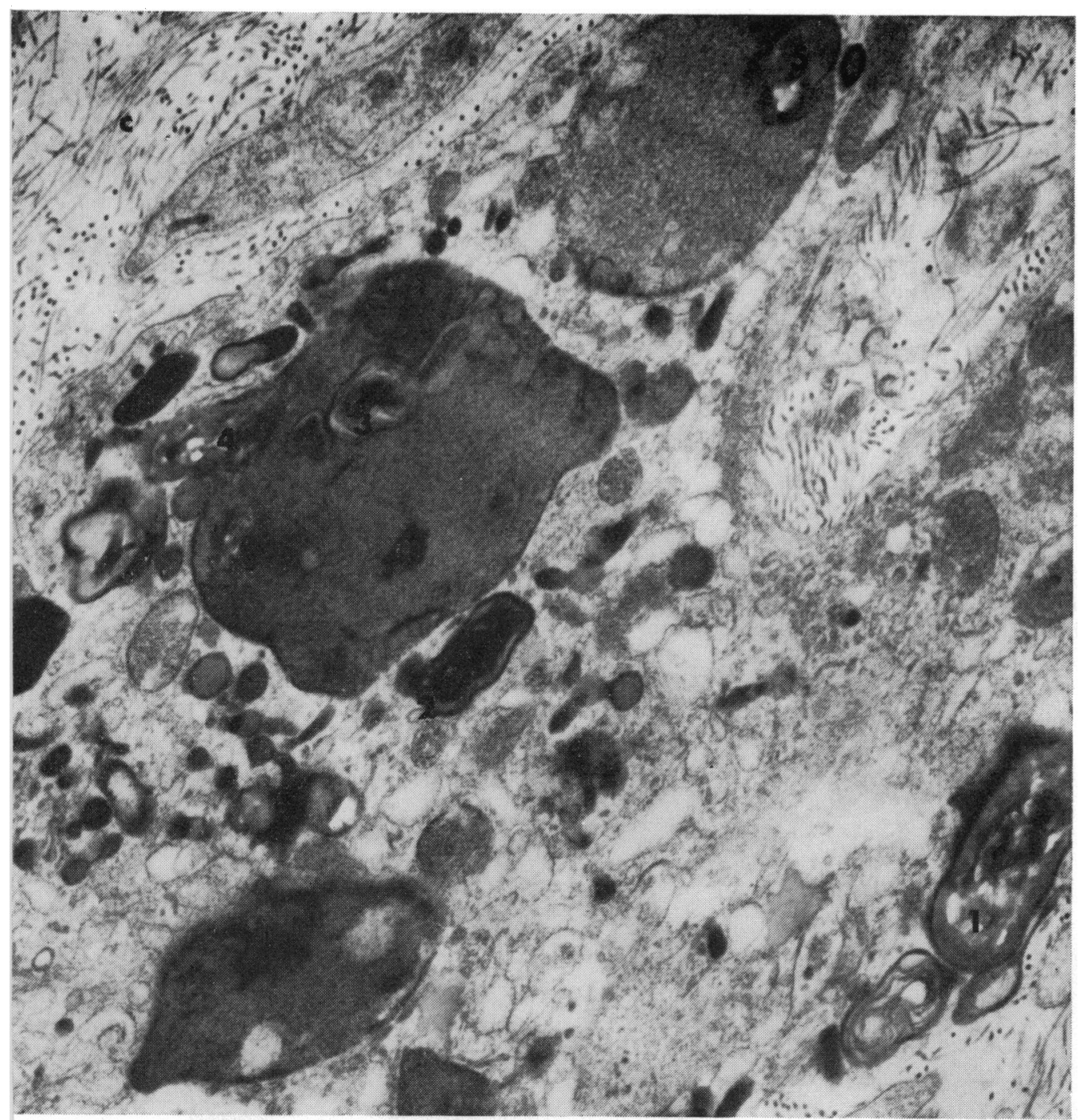

Fig. 9 The

lamina propria of case 5 in Table I

below the

epithelium shown

in Figure 1.

$1=$ extracellular

organism; $2-4$ and

5 are altered

bacilli, and are

near or in

'lysosomes' in a

large macrophage.

$c=$ collagen.

$\times 21,000$

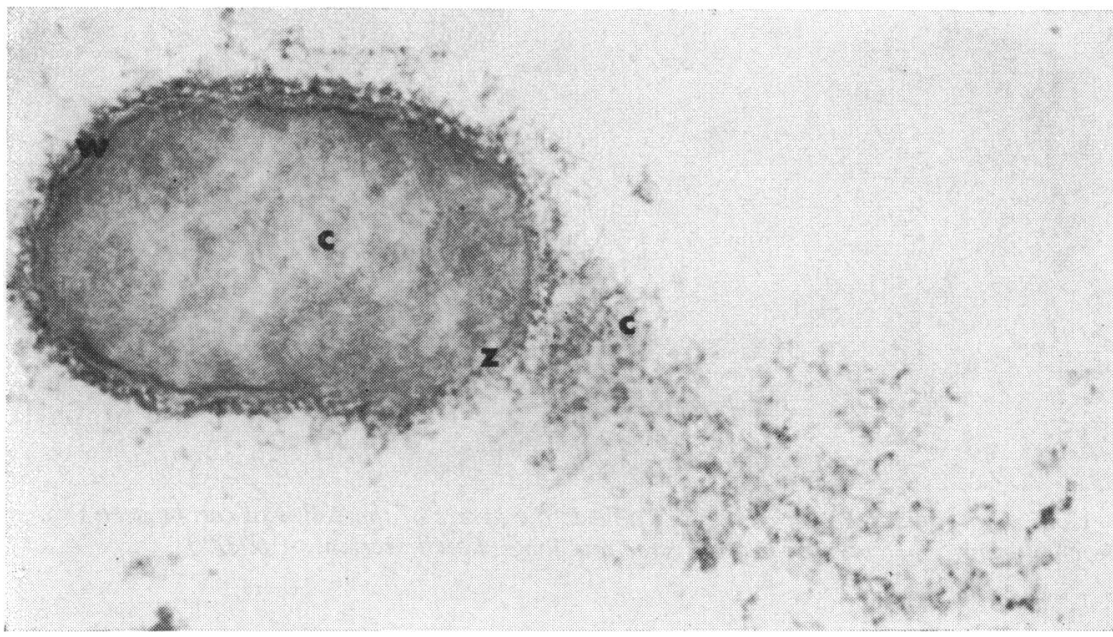

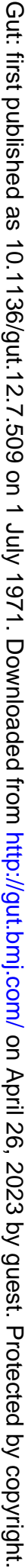

Fig. 10 Disintegrating bacillus in the submucosa in case 1 in Table $I . w=$ multilayered cell wall which is breaking up near ' $z$ ' releasing intracellular substance $(c) . \times 75,000$ 
Gram staining. None of the patients had had any drug therapy for Crohn's disease. Organisms were not seen in any of the normal colons or in any of those with ulcerative colitis and intact epithelium. The appearance of the bacteria was not the same in all cases. Figure 10 shows a degenerating bacillus in the submucosa of case 1 in Table I. Figure 11 shows two of several coccoid organisms seen deep in the lamina propria and submucosa of case 2 in Table I. The possible presence of $L$ forms, or 'phageinfected' forms of bacteria is under investigation.

\section{Discussion}

The colon was chosen for study because specimens are easy to obtain and in ulcerative colitis a convenient inflammatory analogue exists with which to compare the changes seen in Crohn's disease.

Epithelial cell abnormality is not a prominent or early feature of Crohn's disease (Aluwihare, 1969), whereas in ulcerative colitis it is more obvious
(Aluwihare and Parks, 1970) and probably occurs earlier (Donnllan, 1966). In ulcerative colitis and other colonic inflammatory diseases the subepithelial fibrous tissue may be affected early (Donnllan, 1966; Gonzalez-Licea and Yardley, 1966a and b), but in Crohn's disease this is not so. It would appear that the epithelial complex is not the site of the primary abnormality in Crohn's disease.

An increase in the proportion of lymphocytes and plasma cells in the lamina propria as compared with the normal colon and that of ulcerative colitis (Aluwihare, 1969) appears to be one of the earliest changes detectable with the electron microscope in Crohn's disease. The prominent and unusual nucleolus seen in the lymphocytes is probably an indication of excessive activity, as a prominent nucleolus has been reported in cells undergoing transformation into plasma cells (Bernhard and Granboulan, 1960). It is also possible that the larger proportion of cells with prominent nucleoli indicates that the

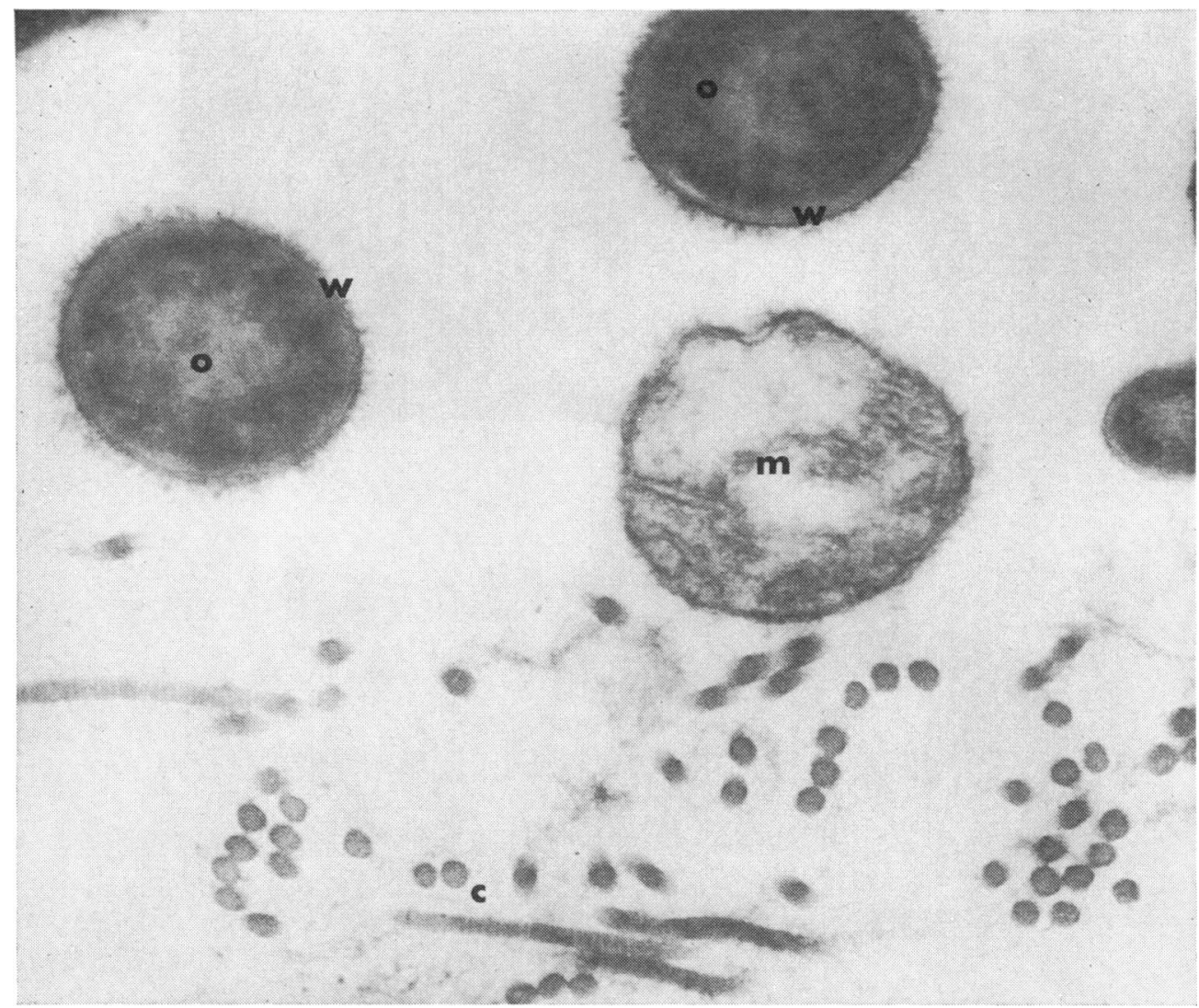

Fig. 11 Coccoid organisms (o) in case 2 in Table I; the layers of the cell wall can be seen $(w) . m=$ loose mitochondrion; $c=$ collagen in transverse and longitudinal section. $\times 60,000$ 
cells are in a state of arrested activity in a manner analogous to the increased proportion of mitotic nuclei seen in tissue after the use of colchicine to cause mitotic arrest. Whichever explanation is the correct one, these findings are in accord with the patchy increased prominence of lymphoid tissue that is detected with the light microscope early in the course of the disease (Lennard-Jones and Morson, 1969).

The epithelioid cells vary in structure but are probably metabolically active (Aluwihare and Parks, 1970; Aluwihare, 1971a), and resemble those seen in beryllium granulomata (Elias and Epstein, 1968), sarcoidosis, the Kveim test, and tuberculosis (Williams, Erasmus, James, and Davies, 1970). Similar findings have recently been described by Albot, Parturier-Albot, Camilleri, and Diebold (1970) in a case of Crohn's disease, but the manner in which they established the identity of the epithelioid cells is not altogether clear. At a light microscopic level epithelioid cells were found to contain acid phosphatase(D. Williams, W. J. Williams, and J. E. Williams, 1969). At an ultrastructural level the clear vesicles contain this enzyme, which is an important constituent and sign of lysosomal vesicles and is usually found with debris or dense bodies in phagocytic cells such as macrophages. The macrophages and epithelioid cells in Crohn's disease resemble each other in most respects but the latter contain much less phagocytosed matter. Nelson (1969) reviews the evidence supporting the view that phagocytosis of certain bacteria by macrophages is completed only when an appropriate antibody has been delivered to the cells by lymphocytes. The lymphocytes are attracted to the macrophage before or just after the ingestion of the foreign matter, multiply, and change into plasma cells which make the appropriate antibody. Then this antibody enables the macrophage completely to ingest, digest, and retain or extrude the foreign matter. This interaction may depend on, and its disturbance result in, changes in permeability of the macrophage. A fault in this mechanism could manifest itself cytologically by qualitative and quantitative changes in the macrophages and lymphocytes, and clinically by a disease in which immune responses are altered. The absence of debris in epithelioid cells may indicate that they are macrophages in a functional state in which they are not exerting their phagocytic potential. Whether or not epithelioid cells and, or, granulomata are seen in any one case, and they are seen in only $50-74 \%$ of the patients with Crohn's disease (LennardJones and Morson, 1969), might be governed by the exact nature of a defective interaction between lymphocytes and macrophages. It is of interest that epithelioid cells and macrophages are often seen very close to lymphocytes, but it is not possible to say from 'still' photographs whether or not such obvious proximity indicates ineffective activity.

In this study particular attention was paid to areas of bowel with intact epithelium and minimal disease. In six untreated patients bacteria were identified in the lamina propria and or submucosa of the colon with the electron microscope but not with the light microscope. The organisms were sectioned within the tissue and were not contaminants. In over 20 mouse colons (Aluwihare, 1971b), six normal colons, and seven colons with ulcerative colitis bacteria were not seen in comparable areas. Nor have they been seen in the colonic wall by any of the many workers who have studied the fine structure of the normal colon (Aluwihare, 1969), or the ulcerative colitic colon (Donnllan, 1966; Gonzalez-Licea and Yardley, 1966a and b). Nor were they seen in the intestinal villi in experimentally induced lymphatic obstruction (Kalima and Collan, 1970). They have been seen in shigellosis (Takeuchi, Sprinz, LaBrec, and Formal, 1965) and Whipple's disease (Watson and Haubrich 1969) where they may be aetiological agents. Their presence in Crohn's disease may therefore be of some aetiological significance, and the patchy distribution of the clusters fits the discontinuous nature of the histology (Lennard-Jones and Morson, 1969). The identification of the organisms by culture techniques is difficult because of the ease with which contamination can occur at this site, and immunoelectron microscopic methods may have to be used. It is of interest that Mitchell and Rees (1970) have suggested the possibility of a transmissible agent in Crohn's disease, and that Dykes (1970) feels that a faecal antigen may be involved.

Whatever part the bacteria might play in initiating the immune response, they may be responsible for the formation of the fissures and the consequences of the transmural fissures, such as fistulae.

In an earlier report it was suggested that the lymphocytes, plasma cells, and macrophages in the lamina propria play an active and important part in the antibacterial and immunological defences of the colon (Aluwihare, 1971b). As discussed earlier, disturbances of the relationships between macrophages and lymphocytes can lead to changes in their morphology, altered immune responsiveness, and disease. Nelson (1969) also reviews the evidence, suggesting that the presence of the epithelioid cell may be a manifestation of some sort of delayed hypersensitivity reaction. Dykes (1970) feels there is a delayed hypersensitivity reaction to a faecal antigen in Crohn's disease. Mitchell and Rees (1970) say that the reaction to the Kveim test is 
similar in Crohn's disease and sarcoidosis; in the latter disease delayed hypersensitivity is depressed. Jones, Housley, Ashurst, and Hawkins (1969), using dinitrochlorobenzene, found evidence of depressed delayed hypersensitivity, and Walker and Greaves (1969) found a reduced response to mitogenic stimulation with phytohaemagglutinin in patients with Crohn's disease. All this, and other recent work reviewed by Lennard-Jones and Morson (1969), and the response to corticosteroid and azathioprine therapy, indicates the existence of an 'altered immune responsiveness' in Crohn's diseasepossibly an abnormal delayed hypersensitivity reaction. The existence of such a state, which might partly be caused by hereditary factors, is supported by the electron microscopic findings of an increased proportion of lymphocytes and plasma cells in the lamina propria, the prominent nucleolus of the lymphocytes, their proximity to macrophages and epithelioid cells, and the structure of the latter group of cells.

Findings presented in this report are consistent with many of the features of Crohn's disease. The results support the hypothesis that in these patients a disordered immune state exists, and that the fortuitous entrance of relatively innocuous faecal bacteria sets up in the wall of the colon a hyperactive but ineffective response and so produces the picture of the disease. Because the antibacterial defences of the colon are modified, the organisms persist and multiply, perhaps in an altered form, and cause the continuation of the disease. The anti-inflammatory and immunosuppressive agents induce remission by depressing the immune response and the excitatory bacteria might be disposed of by nonspecific means or the body could develop a state of immune tolerance to them (Nelson, 1969).

The extension and confirmation of these studies and the identification of the organisms may lead to a better understanding of the aetiology and pathogenesis. On the basis of the evidence presented here it is too early to speculate on the therapeutic role of the long-term use of suitable antibiotics, correctly administered, in combination with established methods of managing Crohn's disease.

I am most grateful to Mr Alan Parks of St. Mark's and The London Hospitals for stimulating my interest in this subject and for his constant help and encouragement. I am indebted to Professor G. Causey and latterly Professor McMinn, of the Anatomy Department of the Royal College of Surgeons of England, and to their staffs, for their assistance in providing facilities for electron microscopy and for their help. I am grateful to the consultant and other staff at St. Mark's Hospital for their help and encouragement. This work was supported by a grant from the MRC.

\section{References}

Albot, G., Parturier-Albot, M., Camilleri, J.-P., and Diebold, J. (1970). La maladie de Crohn colique. IV. Étude cytologique et ultra-structurale des infiltrats inflammatoires plasmocytaires et epithelio-giganto-cellulaires. Sem. Hôp. Paris, 46, 15451566.

Aluwihare, A. P. R. (1969). The effect of neomycin on the colon. M.Chir. Thesis, Cambridge.

Aluwihare, A. P. R. (1971a). The ultrastructure of the colon in Crohn's disease. Proc. roy. Soc. Med., 64, 162-164.

Aluwihare, A. P. R. (1971b). An ultrastructural study of the effect of neomycin on the colon in the human subject and in the conventional and the germ-free mouse. Gut, 12, 341-349.

Aluwihare, A. P. R., and Parks, A. G. (1970). The fine structure of the colon affected by Crohn's disease. (Abstr.) In IVth World Congress of Gastroenterology, Copenhagen, p. 393.

Bernhard, W., and Granboulan, N. (1960). Ultrastructure of immunologically competent cells; In Cellular Aspects of Immunity, Ciba Foundation Symposium, edited by G. E. W. Wolstenholme and M. O'Connor, pp. 99-121. Churchill, London.

Causey, G. (1962). Electron Microscopy: Livingstone, London.

Chears, W. C., Jr., and Ashworth, C. T. (1961). Electron microscopic study of the intestinal mucosa in Whipple's disease. Demonstration of encapsulated bacilliform bodies in the lesion. Gastroenterology, 41, 129-138.

Corrin, B., Clarke, A. E., and Spencer, H. (1969). Ultrastructural localisation of acid phosphatase in the rat lung. J. Anat. (Lond.), 104, 65-70.

Davenport, H. A. (1960). Histological and Histochemical Technics. Saunders, Philadelphia and London.

Donnllan, W. L. (1966). Early histological changes in ulcerative colitis. Gastroenterology, 50, 519-540.

Dykes, P. W. (1970). Delayed hypersensitivity to a faecal antigen in patients with Crohn's disease. In IVth World Congress of Gastroenterology, Copenhagen (Abstr.), 386.

Elias, P. M., and Epstein, W. L. (1968). Ultrastructural observations on experimentally induced foreign body and organized epithelioid cell granulomas in man. Amer. J. Path., 52, 12071223.

Gonzalez-Licea, A., and Yardley, J. H. (1966a). Nature of the tissue reaction in ulcerative colitis, Gastroenterology, 51, 825-840.

Gonzalez-Licea, A., and Yardley, J. H. (1966b). A comparative ultrastructural study of the mucosa in idiopathic ulcerative colitis, shigellosis, and other human colonic diseases. Bull. Johns Hopk. Hosp., 118, 444-461.

Jones, J. V., Housley, J., Ashurst, P. M., and Hawkins, C. F. (1969). Development of delayed hypersensitivity to dinitrochlorobenzenein patients with Crohn's disease. Gut, 10, 52-56.

Kalima, T. V., and Collan, Y. (1970). Intestinal villus in experimental lymphatic obstruction. Correlation of light and electron microscopic findings with clinical diseases. Scand. J. Gastroent., $5,497-510$

Lennard-Jones, J. E., and Morson, B. C. (1969). Changing concepts in Crohn's disease. Disease-a-Month, August. Year Book Medical Publishers, Chicago.

Mitchell, D. N., and Rees, R. J. W. (1970). Agent transmissible from Crohn's disease tissue. Lancet, 2, 168-171.

Nelson, D. S. (1969). Macrophages and Immunity, North-Holland, Amsterdam and London.

Takeuchi, A., Sprinz, H., LaBrec, E. H., and Formal, S. B. (1965). Experimental bacillary dysentery. An electron microscopic study of the response of the intestinal mucosa to bacterial invasion. Amer J. Path., 47, 1011-1044.

Walker, J. G., and Greaves, M. F. (1969). Delayed hypersensitivity and lymphocyte transformation in Crohn's disease and proctocolitis. Gut, 10, 414 .

Watson, J. H. L., and Haubrich, W. S. (1969). Bacilli bodies in the lumen and epithelium of the jejunum in Whipple's disease. Lab. Invest., 21, 347-357.

Williams, D.,Jones Williams, W. J., and Williams, J. E. (1969). Enzyme histochemistry of epithelioid cells in Sarcoidosis and Sarcoidlike granulomas. J. Path., 97, 507-709.

Williams, W. J., Erasmus, D. A., James, V. E. M., and Davies, T. (1970). The fine structure of granulomas in sarcoidosis, the Kveim test, and tuberculosis. J. Path., 100, xiii. 